\title{
DIDACTIC PLANNING ACTIVITY OF INSTRUCTION IN TECHNIQUE
}

\section{Maria RACZYŃSKA}

\begin{abstract}
The purpose of this article is to show the importance of didactic planning activity for lessons of technique. Author presents the principles of planning of didactic units and exemplary plan of instruction in technique.
\end{abstract}

Key words: education, didactic planning, technique.

\section{PLANOWANIE PRACY DYDAKTYCZNEJ W NAUCZANIU TECHNIKI}

Streszczenie: $W$ tekście podjęta została próba zaakcentowania znaczenia, które niesie za soba planowanie pracy dydaktycznej na zajęciach techniki. Autorka przedstawia zasady planowania jednostek dydaktycznych oraz przedstawia przykładowy plan w nauczaniu techniki.

Stowa kluczowe: edukacja, planowanie dydaktyczne, technika.

\section{Wprowadzenie}

Jak nauczać techniki w szkole podstawowej? Jakich sposobów i zabiegów dydaktycznych używać, aby odnieść w swojej pracy sukces rozumiany jako wytworzenie w świadomości swoich uczniów właściwego obrazu pojęć związanych ze współczesną techniką?

Ważnym elementem pracy każdego nauczyciela jest umiejętność planowania dydaktycznego. Jeżeli praca $\mathrm{z}$ uczniem ma przynieść określone efekty dydaktycznowychowawcze musi być zaplanowana w sposób szczegółowy i kompleksowy. Działania nauczyciela $\mathrm{w}$ żadnym wypadku nie mogą być przypadkowe i nieprzemyślane. Pamiętać należy, że najważniejszy w procesie nauczania jest uczeń i jego wszechstronny rozwój. Celem artykułu jest przedstawienie zasad planowania jednostek dydaktycznych oraz przedstawienie takiego planu w nauczaniu techniki.

\section{Istota planowania}

Walory planowania są powszechnie znane. Wiadomo, że planowanie polepsza efekty wszelkiej działalności. Może ono również oddać nieocenione usługi także $\mathrm{w}$ pracy nauczyciela. Planowanie zapoczątkowane przez nauczyciela daje wyczucie kierunku zarówno uczniom, jak i jemu samemu. Planowanie pracy dydaktycznej nauczyciela jest najważniejszym elementem jego warsztatu. Sporządzanie planów edukacyjnych rozpoczyna działania edukacyjne. To również pierwsza czynność kierowania uczeniem się jako pomaganiem uczniom [1, s. 173]. Na plan składają się zadania, który mają być wykonany w określonym czasie. W szkole jest to 10miesięczny okres od września do czerwca. W czasie całego roku szkolnego musi panować ład i porządek w działaniu. Planowanie musi być dostosowane do toku działań, środków i sposobu działania, ale również, a może szczególnie do celów, jak i warunków.

Planowanie to: projektowanie zadań i czynności, którego wynikiem jest plan (...) [2, s. 177]. Powinien on uwzględniać cel i warunki, zadania oraz środki dydaktyczne. Ponadto: cecha dobrego planu jest systematyczność ujęcia uwzględniająca wzajemne stosunki poszczególnych elementów planu iśrodowiskowe możliwości jego realizacji oraz terminy wykonania [2, s. 177]. Świadome i celowe działanie nauczycieli i uczniów wymaga przestrzegania celów, warunków i środków pracy. Plan to uporządkowany ciąg zdarzeń, który: obejmujący takie czynności nauczycieli iuczniów, ukierunkowane przez odpowiedni dobór celów i treści, oraz takie warunki i środki, jakie stuża do wywotywania zmian $w$ uczniach, stosownie do przyjętych celów ksztatcenia. Rola nauczyciela jako głównego przekaźnika szybko ewoluuje. Nauczyciel staje się doradca, przewodnikiem $i$ selekcjonerem wiedzy nabywanej przez ucznia [3, s. 106]. Aby skutecznie planować potrzebne są następujące informacje:

- stan wiedzy uczniów,

- znajomość calego programu przedmiotowego,

- znajomość form, metod $i$ środków jego realizacji,

- znajomość celów i zadań jego ksztatcenia [4, s. 195]. 


\section{Cechy dobrego planu}

Niemal wszyscy teoretycy organizacji i zarządzania podejmujący problematykę planowania pracy zgodnie stwierdzają, że aby plan spełniał pokładane w nim nadzieje, powinien spełniać określone warunki. Nie wystarczy posiadanie jakiegokolwiek planu, powinno planować się dobrze.

Klasyczną w tej mierze koncepcję przedstawił T. Kotarbiński [5, s. 162 in], która wielokrotnie modyfikowana przez różnych autorów, przyjmuje się, że dobrze pomyślany plan pracy powinien m.in. być:

- Celowy - a więc trafnie określać cel i środki prowadzące do jego osiągnięcia;

- Wykonalny - przy dostępnych środkach i określonych warunkach jest prawdopodobieństwo osiągnięcia celu;

- Konsekwentny - spójny wewnętrznie;

- Operatywny - czytelny, zrozumiały i ścisły, nadający się do realizacji zgodnej z porządkiem wykorzystania zasobów i obranego toku działania;

- Elastyczny - w samym planie zawarta jest możliwość jego modyfikacji;

- Dostatecznie szczegółowy - zbyt ogólnikowy nie ma waloru operatywności, nie służy dobrze realizacji celów, a nadmiernie szczegółowy ogranicza swobodę działania;

- W należytym stopniu dtugodystansowy wybiegający w przyszłość w granicach zdolności przewidywania przyszłych okresów;

- Terminowy;

- Kompletny lub zupetny, uwzględniający całość działania;

- Racjonalny - uwzględniać możliwe wszystkie związki przyczynowo- skutkowe zachodzące pomiędzy jego elementami oraz wynikać z rzetelnej znajomości faktów, zjawisk i procesów;

- Sprawny - umożliwiał sprawne działanie na etapie jego realizacji.

Cz. Plewka [6, s. 105] uważa, ,żeby mógt powstać dobry plan pracy, często nie wystarczy koncentrować uwagi jedynie na tym, żeby odpowiadal wyżej wymienionym cechom. Trzeba również zadbać o przestrzeganie zasad planowania pracy, oto, żeby byt wtaściwy tok postepowania przy sporzadzaniu planu pracy"

Plan będzie wtedy dobrze sporządzony, gdy opracujemy go ze szczególną starannością, jeśli będzie uwzględniał zarówno potrzeby, jak i możliwości tych, którzy będą go realizować.

\section{Etapy planowania dydaktycznego}

Nauczyciele posługują się planami dhugoterminowymi (semestralne i roczne) oraz krótkoterminowymi (plany jednostek tematycznych lub metodycznych). Plany roczne odgrywają bardzo ważną rolę planowaniu pracy dydaktyczno - wychowawczej. Skuteczność planów rocznych wymaga określenie postaw, celów idei, w które powinni zostać wyposażeni uczniowie po zakończeniu procesu kształcenia oraz zastanowienia się nad treściami kształcenia. Opracowanie dobrego planu wymaga znajomości celów kształcenia ogólnego [7, s. 395]. Kolejnym krokiem jest rozplanowanie treści na poszczególne jednostki metodyczne.

B. Niemierko [8, s. 142-151] planowanie nauczania dzieli na trzy etapy:

- Planowanie kierunkowe - obejmuje swym zasięgiem rok szkolny, semestr, określające kolejne tematy, cele nauczania, typ lekcji, metodę i przebieg zajęć. Polega ono na powiązaniu celów z materiałem nauczania. W trakcie planowania kierunkowego podejmuje się decyzje, które fragmenty materiału nauczania umożliwią osiągnięcie poszczególnych celów kształcenia.

- Planowanie wynikowe - obejmuje swym zasięgiem dział programowy, rozdział, określa materiał nauczania, wymagania programowe. Umożliwia ono określenie wymagań w odniesieniu do kolejnych lekcji. Dzięki tym ustaleniom możliwa jest ocena osiągnięć uczniów oraz skuteczności pracy nauczyciela. Planowanie wynikowe, związane jest $\mathrm{z}$ określoną jednostką metodyczną, to zaplanowanie realizacji spójnej logicznie dawki materiału nauczania i odpowiadających jej umiejętności. Treść jednostki może odpowiadać rozdziałowi podręcznika lub działowi programowemu. Planowanie jednostek metodycznych odgrywa bardzo ważną rolę, ponieważ pozwala na całościowe spojrzenie na realizowane cele, treści i czynności, które nauczyciel będzie realizował $\mathrm{z}$ uczniami na kolejnych lekcjach w okresie kilkudniowym lub dłuższym [9, s. 84-85].

- Planowanie metodyczne - obejmuje swym zasięgiem lekcję, jednostkę metodyczną, związane jest $\mathrm{z}$ określeniem wymagań programowych oraz $\mathrm{z}$ przebiegiem zajęć. Ostatni etap planowania zajęć dydaktycznych czyli planowanie metodyczne, polega na opracowaniu konspektu lekcji (scenariusza zajęć) czyli na 
planowaniu przebiegu zajęć dydaktycznych, umożliwiającym uczniom osiąganie określonych celów kształcenia. Plany jednostek metodycznych sporządzane są dokładnie. Materiałami, na których opiera się nauczyciel w trakcie planowania nauczania są: podstawa programowa i program nauczania.

\section{Plan pracy dydaktycznej - rozkład materiału nauczania}

Nauczyciel przygotowując się do realizacji zadań dydaktycznych w nowym roku szkolnym, w pierwszej kolejności analizuje podstawę programowa i program nauczania. Stanowią one podstawę do opracowania szczegółowych rozkładów materiału nauczania. „Szczegółowy rozkład jest dokumentem obowiazujacym każdego nauczyciela i zawiera wykaz (katalog) tematów kolejnych jednostek metodycznych oraz czasu przeznaczonego na ich realizacje. Dokument ten odnosi sie do konkretnego przedmiotu i poziomu nauczania" [10, s. 111].

Jednostka metodyczna to zespół (układ) kolejnych jednostek lekcyjnych stanowiący logiczny ciąg procesu dydaktycznego zmierzający do przekazania (przyswojenia) wiadomości, kształtowania umiejętności i uzyskania sprawności w obrębie jednego tematu (wydzielonego fragmentu programu nauczania), który zakresem jest zbyt obszerny na jedną jednostkę lekcyjną lub osiągnięcia zamierzonego (zamierzonych) celu. W literaturze jednostka lekcyjna definiowana jest jako forma organizacyjna procesu nauczania - uczenia się w systemie klasowo lekcyjnym, która umożliwia w ściśle określonym czasie (45 minut) zrealizowanie wyodrębnionej części programy nauczania lub realizując wcześniej określone czynności procesu nauczania - uczenia się osiągnięcie zakładanego celu [10, s. 112]. Coraz powszechniej przyjmuje się, że jednostki lekcyjnej (lekcji) nie można traktować jako wyodrębnionej i wyizolowanej jednostki w procesie dydaktycznym, lecz jako element zbioru powiązanego zarówno z lekcjami poprzedzającymi, jak i z tymi, które po nich nastąpią. Materiał nauczania zawarty w rozkładzie nauczania jest podzielony na poszczególne jednostki metodyczne. Większą partię materiału nauczania stanowi jednostka tematyczna, która składa się pewnej liczby jednostek metodycznych. Sporządzanie rozkładu przed każdym okresem (semestrem) roku szkolnego pozwala na wcześniejsze przemyślenie doboru i układu treści oraz dostosowanie do nich formy i metody pracy. Dobrze sporządzony rozkład materiału nauczania powinien zawierać między innymi tematy poszczególnych jednostek metodycznych, liczbę godzin przeznaczonych na realizację każdego tematu. W planie są określone cele operacyjne dotyczące wiadomości i umiejętności, metody nauczania i środki dydaktyczne oraz uwagi o realizacji.

W trakcie opracowania rozkładu materiału nauczania istotne jest aby:

- rozkład materiału nauczania dotyczył całego cyklu kształcenia, a nie tylko jednego roku czy semestru,

- w uzasadnionych przypadkach, np. jeśli program nauczania nie został $\mathrm{w}$ pełni zrealizowany w danym roku, wtedy możemy przenieść treści kształcenia na następny rok,

- zachodziła korelacja międzyprzedmiotowa,

- treści jednej jednostki lekcyjnej łączyły się tematycznie z treściami następnej,

- przewidzieć czas na utrwalenie przerobionego materiału oraz kontrolę wiedzy i umiejętności,

- opracowanie podziału treści kształcenia każdego działu programowego najlepiej rozpocząć od wyliczenia tego, co uczący się powinien wiedzieć i co powinien umieć po zrealizowaniu treści określonego działu programowego, a dopiero $\mathrm{W}$ dalszej kolejności zdecydować, które z tych celów zostaną osiągnięte $\mathrm{w}$ poszczególnych jednostkach, by ustalić ich temat i czas trwania. Dopiero na końcu ustalić metodę nauczania i środki dydaktyczne,

- w rozkładzie znalazła się rubryka na ewentualne uwagi, które mogą okazać się pożyteczne w kolejnym planowaniu.

Rozkład materiału nauczania przyjmuje różne formy najczęściej tabelaryczną. Projekt rozkładu materiału nauczania danego przedmiotu jest zatwierdzany do realizacji przez dyrektora szkoły, wtedy stanowi plan dydaktyczny.

Przedstawiony poniżej fragment rozkładu materiału nauczania $\mathrm{z}$ techniki w kl. 4-6 jest dosyć rozbudowany (Tabela 1: Projekt szczegółowego rozkładu nauczania techniki w klasach IV szkoły podstawowej). Jego strukturę stanowią: tematy jednostek metodycznych, ilość godzin przypadających na daną jednostkę, cele operacyjne, metody i strategie nauczania, środki dydaktyczne. Taka forma planu jest pracochłonna, gdyż nauczyciel projektując go musi przeprowadzić szczegółową analizę treści 
nauczania zawarte $\mathrm{w}$ programie nauczania oraz mieć wizję każdej przyszłej jednostki metodycznej (lekcji). W rozkładzie cele operacyjne zostały przedstawione $\mathrm{w}$ postaci wiadomości i umiejętności jakie powinien posiąść uczeń po zrealizowaniu każdej jednostki metodycznej oraz metody nauczania, które służą do osiągania celów. Rozkład materiału tak jak i inne plany można modyfikować, czyli wprowadzać w nich niezbędne zmiany. Dobrze opracowany plan dydaktyczny stanowi podstawę do dalszego projektowania i planowania dydaktycznego jednostek lekcyjnych.

Tabela 1. Projekt szczegółowego rozkładu nauczania techniki w klasach IV szkoły podstawowej

\begin{tabular}{|c|c|c|c|c|c|c|}
\hline \multirow{2}{*}{$\begin{array}{c}\text { Tematy } \\
\text { jednostek } \\
\text { metodycznych }\end{array}$} & \multirow{2}{*}{ 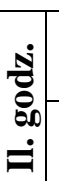 } & \multicolumn{2}{|c|}{$\begin{array}{c}\text { Wynikające z celów } \\
\text { dydaktycznych }\end{array}$} & \multirow{2}{*}{$\begin{array}{c}\text { Metody, } \\
\text { strategie } \\
\text { nauczania }\end{array}$} & \multirow{2}{*}{$\begin{array}{c}\text { Środki } \\
\text { dydaktyczne }\end{array}$} & \multirow{2}{*}{ סू } \\
\hline & & Wiadomości & Umiejętności & & & \\
\hline $\begin{array}{l}\text { Rozpoznawani } \\
\text { e sytuacji } \\
\text { technicznej - } \\
\text { podstawka } \\
\text { do krojenia } \\
\text { produktów } \\
\text { spożywczych } \\
\text { lub łopatka do } \\
\text { patelni } \\
\text { (rozpoznawanie) }\end{array}$ & & $\begin{array}{l}\text { znaczenie } \\
\text { nazw; } \\
\text { znaczenie } \\
\text { wtaściwości } \\
\text { i cech } \\
\text { przedmiotów; }\end{array}$ & $\begin{array}{l}\text { analiza } \\
\text { sytuacji } \\
\text { problemowej; } \\
\text { wybór } \\
\text { istotnych } \\
\text { elementów } \\
\text { sytuacji; } \\
\text { nazywanie } \\
\text { wytworów } \\
\text { i zjawisk } \\
\text { technicznych; }\end{array}$ & $\begin{array}{l}\text { metoda } \\
\text { problemowa; }\end{array}$ & $\begin{array}{l}\text { proste przed- } \\
\text { mioty jedno- } \\
\text { elementowe } \\
\text { wykonane } \\
\text { przez uczniów; }\end{array}$ & \\
\hline $\begin{array}{l}\text { Projektowanie } \\
\text { deski do } \\
\text { krojenia } \\
\text { produktów } \\
\text { spożywczych } \\
\text { (projektowanie) }\end{array}$ & & $\begin{array}{l}\text { istota } \\
\text { projektowania } \\
\text { zasady } \\
\text { projektowania; } \\
\text { zawód } \\
\text { projektanta } \\
\text { i zakres jego } \\
\text { czynności; }\end{array}$ & $\begin{array}{l}\text { analizowanie } \\
\text { funkcji } \\
\text { wybranego } \\
\text { przedmiotu } \\
\text { z otoczenia; } \\
\text { formułowanie } \\
\text { założeń } \\
\text { projektowych, } \\
\text { uwzględnianie } \\
\text { wymagań } \\
\text { techniczno-- } \\
\text { użytkowych }\end{array}$ & $\begin{array}{l}\text { metoda } \\
\text { projektów; } \\
\\
\text { strategia } \\
\text { operacyjno- } \\
\text { problemowa }\end{array}$ & $\begin{array}{l}\text { próbki } \\
\text { różnych } \\
\text { materiałów: } \\
\text { metal, } \\
\text { drewno, } \\
\text { tworzywa } \\
\text { sztuczne; }\end{array}$ & \\
\hline $\begin{array}{c}\text { Poznajemy } \\
\text { podstawowe } \\
\text { metody } \\
\text { konstruowania } \\
\text { (konstruowanie) }\end{array}$ & & $\begin{array}{l}\text { istota } \\
\text { konstruowania } \\
\text { zasady } \\
\text { konstruowania } \\
\text { podstawowe } \\
\text { właściwości } \\
\text { materiałów } \\
\text { drzewnych; } \\
\text { zasady } \\
\text { szkicowania } \\
\text { technicznego; } \\
\text { zawód } \\
\text { konstruktora } \\
\text { i jego } \\
\text { czynności; }\end{array}$ & $\begin{array}{l}\text { badanie } \\
\text { podstawowyc } \\
h \text { wtaściwości } \\
\text { materiałów } \\
\text { drzewnych: } \\
\text { twardość, } \\
\text { nasiąkliwość, } \\
\text { wytrzymałość } \\
\text { na zginanie; } \\
\text { szkicowanie } \\
\text { techniczne } \\
\text { różnych } \\
\text { przedmiotów; } \\
\text { przygotowanie } \\
\text { szablonu }\end{array}$ & $\begin{array}{l}\text { pogadanka } \\
z \\
\text { instruktażem } \\
\text { ćwiczenia } \\
\text { przedmiotowe } \\
\\
\text { strategia } \\
\text { operacyjna }\end{array}$ & $\begin{array}{c}\text { próbki } \\
\text { różnych } \\
\text { gatunków } \\
\text { drewna; } \\
\text { narzędzia } \\
\text { i przyrządy } \\
\text { do } \\
\text { przeprowa- } \\
\text { dzenia prób. }\end{array}$ & 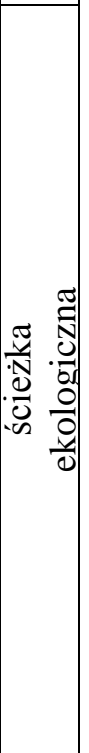 \\
\hline
\end{tabular}




\section{Zakończenie}

Jednym $\mathrm{z}$ warunków prowadzących do sukcesów w procesie nauczania - uczenia się jest dobre planowanie pracy dydaktycznej na określony czas nauki szkolnej oraz umiejętne przygotowywanie się do zajęć dydaktycznych. Aby dobrze planować należy posiadać odpowiednią wiedzę $\mathrm{z}$ zakresu planowania. Nauczyciel techniki (tak jak i inni nauczyciele) z początkiem każdego roku szkolnego opracowuje dwa zasadnicze plany: roczny plan dydaktyczny oraz plany jednostek metodycznych. Zanim przystapi do planowania rocznego najpierw musi dokonać szczegółowej analizy treści programu nauczania. Celem tego rodzaju planowania jest pogrupowanie treści materiału w odpowiednie jednostki tematyczne i wzajemnie je powiązanie. Jest to zadanie trudne, gdyż wymaga ze strony planującego wiele przemyśleń, tworzenia różnych koncepcji lekcji. Dobrze opracowany rozkład materiału nauczania stanowi podstawę do planowania jednostek metodycznych.

\section{Literatura}

[1] NIEMIERKO, B., Kształcenie szkolne. Podręcznik skutecznej dydaktyki. Wyd. Akademickie i Profesjonalne. Warszawa 207, s. 173. ISBN 978-83-60807-11-8.

[2] NOWACKI T. Leksykon pedagogiki pracy, Wyd. ITE, WSP ZNP, WSP TWP, Radom 2004, s. 177. ISBN 83-7204-335-3.

[3] SZYNKOWSKA, Z., Co w planowaniu piszczy? w: Pedagogika. Prace naukowe $\mathrm{Nr}$ 1/11/2004, s. 106. ISSN 1429-4656.
[4] PÓŁTURZYCKI, J. Dydaktyka dla nauczycieli. Wyd. Adam Marszałek. Toruń 1999, s. 195. ISBN 83-7322-365-7.

[5] KOTARBIŃSKI, T.: Traktat o dobrej robocie. Wyd. 6, Wrocław Warszawa Kraków Gdańsk, Wyd. Zakłąd Narodowy im. Ossolińskich 1975, s. 162 i nast.

[6] PLEWKA, Cz., Metodyka nauczania teoretycznych przedmiotów zawodowych. Podręcznik dla kandydatów na nauczycieli, cz.2, Wyd. ITE, Radom 1999, s.105. ISBN 83-7204076-1.

[7] OKOŃ, W., Wprowadzanie do dydaktyki ogólnej, Wyd. Akademickie „Żak”, Warszawa 2003, s. 395. ISBN 83-86770-21-X..

[8] NIEMIERKO, B., Między oceną szkolną a dydaktyką. Bliżej dydaktyki. Warszawa 1997, WSziP, s.142-151. ISBN 83-02-06459-9.

[9] ARENDS, R.I.: Uczymy się nauczać. WSiP, Warszawa 1994, s.84-85. 83-02-05532-8.

[10] PLEWKA, Cz., Metodyka nauczania teoretycznych przedmiotów zawodowych. Podręcznik dla kandydatów na nauczycieli, cz.2, Wyd. ITE. Radom 1999, s.111-112. ISBN 837204-076-1.

dr Maria Raczyńska

Instytut Informatyczno-Techniczny

Wydzial Nauczycielski

Politechnika Radomska

Ul Malczewskiego 20 a

26-600 Radom, PL

Tel: +48 483617815

E-mail: raczmar@wp.pl 